\title{
A QUESTÃO DO CORPO E SEXUALIDADE NA FORMAÇÃO DOCENTE
}

\section{The question of the body and sexuality in the teaching formation}

\section{Suzana Lyra Strapasson}

Analista Junguiana Didata e membro da Associação Junguiana do Brasil, Curitiba, PR Brasil, e-mail: lyra.suzana@gmail.com

\section{Resumo}

O presente trabalho tem o objetivo de esclarecer alguns aspectos da questão do corpo e da sexualidade na formação docente na perspectiva da psicologia e, para isso, o caminho percorrido é: do signo ao símbolo, do profano ao sagrado. Eros, o deus do amor, ou o próprio amor, é o representante maior da afetividade e da sexualidade. É Eros quem dá inteligência e coração à sexualidade. Eros tem duas faces, uma escura e uma luminosa. O seu lado escuro não deve ser simplesmente rejeitado ou negado, por ser desconhecido e ameaçador, mas sim acolhido e compreendido, e com isto, transformado. Para tal, precisase de conhecimento. Não apenas do conhecimento informativo, mas de um conascimento, de um nascer com, de um emergir do conhecimento que nasce da experiência profunda do cotidiano e se mostra em palavras, gestos, tom de voz, no olhar, enfim, no corpo.

Palavras-chave: Corpo. Sexualidade. Afetividade. Eros. Símbolo. 


\section{Abstract}

This paper intends to clarify some aspects of the issue of the body and the sexuality in the teaching training under the perspective of psychology and, for this, the chosen path is: from the sign to the symbol, from the profane to the sacred one. Eros, the god of love, or the proper love, is the biggest representative of the affections and the sexuality. It is Eros that provides intelligence and heart to the sexuality. Eros has two faces, a dark and a luminous one. Its dark side should not simply be rejected or denied for being unknown and threatening, but otherwise should be received and understood, and thus, transformed. For such, knowledge is needed. Not only the informative knowledge, but a co-birth, one to be born with, and one to emerge from the knowledge that comes from the deep day-by-day experience and is shown in words, gestures, voice tone, gaze, at last, in the body.

Keywods: Body. Sexuality. Affection. Eros. Symbol.

\section{INTRODUÇÃO}

A formação docente tem se manifestado o ponto de convergência de questões pertinentes aos mais diversos campos do existir humano. Corpo e sexualidade na formação docente é, aqui, mais do que algumas páginas decorrentes de uma minuciosa pesquisa desenvolvida, uma temática que encontra na formação docente sua maior pertinência. Em que sentido?

Na cultura ocidental tem-se refletido sobre questões como: o que é o masculino e o que é o feminino, o que é ser homem, o que é ser mulher. Estas questões remetem a uma pluralidade de outras para as quais as tentativas de respostas não são simples. Essas questões surgem em decorrência de crises surgidas nas relações entre gêneros, entre as classes e entre as raças. Como então conceituar a sexualidade, se para isso tem-se que definir o ser humano em todos os aspectos?

A sexualidade é expressão da personalidade do individuo, é sinônimo de comunicação, e esta varia de indivíduo para indivíduo. O termo gênero é amplamente usado para se referir aos modos em que a cultura reformula o que começa como um fato da natureza. Os sexos biológicos são redefinidos, representados e valorizados para diferentes papéis. Sabe-se que o instinto sexual, em todos os seres vivos, é o elemento fundamental sem o qual não haveria a continuação dos ciclos da vida. Não existe no homem

Rev. Diálogo Educ., Curitiba, v. 9, n. 27, p. 363-378, maio/ago. 2009 
nenhum instinto que não seja mantido em equilíbrio por outro instinto. Eis porque a questão do corpo e da sexualidade na formação docente emerge aqui como ponto de partida de reflexão e análise!

\section{Identidade e corpo}

A cultura busca determinar ao homem como este deve pensar, sentir ou perceber, mas isso não exclui que, enquanto seres humanos, não possuam motivações orgânicas que resultam em determinados tipos de comportamento que independe da cultura à qual se pertença. Mesmo assim, cada cultura atribui a estas motivações biológicas uma significação específica, tendo como consequência a valorização de determinadas atitudes e a desconsideração de outras, selecionando, assim, os impulsos a serem inibidos ou estimulados, enfatizados ou desconsiderados. Quando um determinado grupo elege determinadas características e atributos físicos, emocionais, psicológicos e mentais, entre as inúmeras possibilidades apresentadas pela natureza, cria uma identidade, uma feição própria, que diferencia o mesmo dos demais.

A personalidade do indivíduo implica em estrutura e desenvolvimento. Toda manifestação do comportamento depende da existência de algum tipo de estrutura psíquica dinâmica. Considerando a dificuldade dos problemas no campo da sexualidade, faz-se necessário distingui-la em três fases da vida humana:

A primeira fase compreende os primeiros anos de vida; este período foi denominado por Carl Gustav Jung (1875-1961), estágio pré-sexual e corresponde ao estágio de lagarta da borboleta. Pode-se trabalhar aqui com analogias: a princípio a lagarta fica incubada no casulo à espera de crescimento, maturação e transformação; o ser humano encontra-se assim, num primeiro momento, em dependência física e emocional do outro. Esta fase caracteriza-se quase exclusivamente pelas funções de crescimento, de nutrição e autopreservação. Os cinco primeiros anos de vida são decisivos na formação da personalidade.

A segunda fase compreende os últimos anos da infância até a puberdade e pode ser chamada: período da pré-puberdade. É nesse período que a sexualidade germina. É uma fase de reorganização intrapsíquica. O crescente desenvolvimento da sexualidade influencia nas sensações e sentimentos dando um colorido erótico às percepções. Como na puberdade a maturidade dos órgãos sexuais é alcançada, a genitalidade ocupa o primeiro plano e domina os impulsos pré-genitais.

A terceira fase é a da idade adulta e se estende da puberdade para diante. Podemos chamá-la período da maturidade. Aqui o indivíduo deixa de ser um mero aprendiz e passa a ter uma identidade formada. É capaz de viver intimamente com outra pessoa; há um ajustamento profissional e está apto para associar-se com outras pessoas em condições de igualdade. Sem dúvida, não é possível colocar limites cronológicos a estes

Rev. Diálogo Educ., Curitiba, v. 9, n. 27, p. 363-378, maio/ago. 2009 
períodos, os quais, do ponto de vista energético, são formas de manifestação da libido. Jung sente a necessidade de libertar o conceito de libido das amarras de sua formulação sexual e insiste que a sexualidade deve ser tomada em seu sentido mais amplo.

A partir do segundo e terceiro períodos, a sexualidade pode passar a ser confundida com amor. A questão aqui é que, um dos afetos mais poderosos confundese com a sexualidade e, quanto mais inconsciente for o afeto, quanto mais comprometido o campo relacional do indivíduo, tanto mais intensamente atuará o instinto sexual. De acordo com o pensamento de Jung (JUNG, 1993, p. 99) "O amor é sempre um problema em qualquer idade. Na infância é o amor dos pais; para o ancião, o problema é saber o que fez do seu amor. O amor é uma das grandes forças do destino que vai do céu até o inferno." Esse tão variado fenômeno envolve, praticamente, todos os aspectos da vida humana: é uma questão social, ética, psicológica, filosófica, estética, religiosa, médica, jurídica, fisiológica, etc., cuja dificuldade máxima encontra-se como um problema individual. Thomas Merton dizia que se quisermos compreender a história social e política do ser humano de hoje, precisamos conhecer o inferno, que é justamente o não amar, é a ausência de Eros no indivíduo que reflete na coletividade.

Vive-se segundo padrões culturais que devem ser vistos como um conjunto de mecanismos de controle e que governam o ser humano. Na dimensão coletiva tem-se um grande mosaico composto de grande diversidade de indivíduos singulares, com aptidões e tendências também singulares. Em Grande Sertão: Veredas, Guimarães Rosa (1986) fala em singularidade, diz que o importante e bonito do mundo é isso: que as pessoas não estão sempre iguais, não foram terminadas, mas que elas vão sempre mudando. Afinam e desafinam.

É a identidade pessoal que dá ao indivíduo o sentido de pertencer a si próprio, ter um domínio sobre suas escolhas, uma ideia do caminho que deve seguir diante de suas decisões e escolhas. No entanto, essa mesma identidade exige uma identificação psicológica do próprio sexo biológico, homem/mulher. Afirmações do tipo: mulheres são emotivas e homens são objetivos, servem para definir, restringir e justificar as esferas de ação e os comportamentos "adequados" a cada sexo. Se o mundo objetivo, público, é regido pela competição e pelo pensamento racional, adequou-se isso ao mundo dos homens, e se, às mulheres o mundo das emoções, privado, pessoal, subjetivo, então, coloca-se a elas a responsabilidade pelas relações. Mas dividir funções e esferas de acordo com o sexo traz como efeito a discriminação e a desqualificação de ambos. Tanto o homem como a mulher estão impregnados por estereótipos. É simplesmente esquecer que tanto o homem quanto a mulher, vivem em si uma totalidade abrangente e não restrita por uma cultura de tabus. Mulheres competitivas, que fazem uso mais da razão e da lógica em sua relação com o mundo são criticadas e sua feminilidade é posta em dúvida, bem como, homens que são cooperativos, amorosos, que valorizam seus relacionamentos afetivos, tem sua virilidade colocada em dúvida.

Rev. Diálogo Educ., Curitiba, v. 9, n. 27, p. 363-378, maio/ago. 2009 
Para o ser humano, possuir uma determinada configuração anatômica e fisiológica significa também possuir um status social, cujos limites, direitos e deveres estão devidamente convencionados às expectativas do coletivo. $\mathrm{O}$ ser humano tem sua identidade sexual psicológica determinada não somente pelo aspecto biológico, mas essencialmente pela cultura que, por sua vez, se baseia em crenças a respeito do mundo e dos papéis nele desempenhados. Parece que as preocupações básicas do ser humano não se diferenciaram muito desde os primórdios, pois o homem continua em busca da comida, de proteção, da relação com outros da espécie, a procriação, enfim, a busca de sentido pela vida. O que mudou na verdade é a forma de se buscar isso. Carl Gustav Jung denominou libido à energia psíquica tomada num sentido amplo. Energia psíquica e libido são sinônimas. Libido é apetite, é instinto permanente de vida que se manifesta pela fome, sede, sexualidade, agressividade, necessidades e interesses os mais diversos. Essas seriam expressões múltiplas da energia psíquica, pois o psiquismo do homem (consciente e inconsciente) é concebido como um sistema energético relativamente fechado, possuidor de um potencial que permanece o mesmo em quantidade através de suas múltiplas manifestações, durante toda a vida de cada indivíduo.

No âmbito do dinamismo psíquico, a afetividade é considerada como o fundamento e a causa das contínuas transformações das representações conscientes e inconscientes. Ao mesmo tempo, devido à teoria da libido conjugada com a concepção energética da psique, cada produto singular da afetividade, ou seja, o afeto passa a ser considerado como uma expressão qualitativa da quantidade de energia pulsional. Nesta perspectiva, fala-se do dinamismo psíquico como um verdadeiro jogo cuja correspondência é expressa por uma pluralidade de representações afetivas (diferentes pelo seu significado e intensidade), que diferem sempre (quanto à intensidade e ao significado) das situações gerais consolidadas no processo psíquico.

Em geral, se pensa no corpo como um esqueleto envolvido por músculos e recheado de órgãos. Esquece-se que o mundo existe em função de um corpo que traz em si, a experiência de se estar vivo. Que é o cérebro que cria o tempo linear e objetifica eventos. O corpo organiza a sensação que emerge do metabolismo tissular (camadas que expressam energia, ação, informação), e isso é o que se chama consciência. Segundo Stanley Keleman (1999, p. 45):

A experiência é parte do processo auto-organizador do corpo, um padrão de resposta, pelo qual o corpo sabe aquilo que é e o que está em via de ser. Nesse sentido, o fluxo de experiência na forma de emoções, movimentos, sensações, cria no cérebro uma imagem anatômica do que está acontecendo ou do que já aconteceu.

Nada disso ocorre sem passar pela via da afetividade.

Rev. Diálogo Educ., Curitiba, v. 9, n. 27, p. 363-378, maio/ago. 2009 


\section{Relacionamentos e afetividade}

O Homem lançou-se em uma assustadora divisão que representa uma ferida íntima para cada um. Deixou de lado uma intimidade real para viver um mundo de relações fragmentadas e superficiais. A referência aqui é a relacionamentos entre dois seres que não estão ligados pelo Eros no mesmo espírito, e, quando o ato não tem alma, ambos sentem-se objetos. Amar não é apenas uma relação de pessoa a pessoa, é um estado de atenção, na verdade, atenção a tudo que vive e respira. Sabe-se o quão difícil é sintonizar ritmos, entrar em ressonância com o ritmo do outro, mas acima de tudo precisa-se estar aberto para a realidade do outro.

O que se vê nos relacionamentos, é a eterna espera que o outro se responsabilize pela alegria, pelo dar certo, que seja a tal "cara metade" que vai deixar o mundo colorido. Isso é parte da projeção do ideal humano. Toda projeção é inconsciente a priori, até mesmo necessária, mas a mesma precisa ser conscientizada, somente a partir do momento em que cada um assume a responsabilidade pela sua própria existência, é que pode haver possibilidades de uma relação saudável, o que exige uma colaboração e ajuda mútua. Quando as exigências individuais não são levadas a sério, conduzem a uma guerra entre os parceiros e, atos lamentáveis impedem a intimidade real. Infelizmente, com demasiada frequência parece que quando de um encontro a dois, imediatamente ambos tentam esquecer ou ainda, ignoram a individualidade do outro. As pessoas tentam se tornarem indispensáveis criando relações de dependência nas quais a tensão gerada só pode causar sofrimento a ambos. Poder-se-ia perguntar: até quanto o ser humano consegue ser feliz?

A palavra amor tornou-se piegas, ouve-se as pessoas dizerem: tudo que é muito doce enjoa fácil, cadê o sal? Cadê a dor e o sofrimento? Seria pelo fato de na infelicidade ter-se a sensação de existir? Sim porque quando infelizes, adentra-se na tristeza, na melancolia, na doença, bem como se busca reconquistar coisas e pessoas perdidas. Eis a complexidade do existir. Frequentemente associa-se o estado de bem-aventurança à ascese e à rigidez. Tem-se a ideia de que a alegria é estática e monótona, mas seu contrário é muito trabalhoso, viver a alegria numa vibração diferenciada, exige muita consciência de si mesmo, do outro e do mundo. Precisa-se fazer uso de todos os sentidos, da alma, do espírito que são partes integrantes do corpo. Todo relacionamento existe com uma dinâmica própria que inclui os dois indivíduos, bem como exige uma base determinada em princípios.

Quando ainda na divisão, na ausência de totalidade, o ser humano vive num estado egocêntrico e individualista; depara-se com casais simbióticos, que não tem vida própria, homens e mulheres que vivem em plena dependência

Rev. Diálogo Educ., Curitiba, v. 9, n. 27, p. 363-378, maio/ago. 2009 
dos afetos do outro, mas estar afetado também quer dizer estar doente, despersonalizado. Tornam-se afetados pelo controle do outro, pela manipulação via doença, pela sensualidade, pela carência, pelo autoritarismo, enfim, não existem ainda como indivíduos (no sentido de não divididos). Parece que tudo fica no âmbito dos afetos de forma negativa. Como tonalidade psíquica em geral, a afetividade é considerada uma parte essencial da psique e pode ser delineada enquanto estrutura participante da constituição psíquica e enquanto função essencial do dinamismo psíquico.

A afetividade é descrita como uma estrutura elementar presente desde o nascimento do indivíduo, presidindo ao pensamento e à ação, ao intelecto e à vontade. É considerada também uma função psíquica distinta e autônoma, com relação às funções psíquicas de tipo perceptivo e intelectual, e participante com estas enquanto "tom afetivo." Como tal, sua presença é indicada seja nas formações psíquicas simples ou nas complexas, pelo que se fala de "tonalidade afetiva das imagens" e de "complexos de tonalidade afetiva". Os complexos são os pontos de "nós", os núcleos onde se instala o não digerido, o não aceito, o conflitante, que se formam a partir das experiências pessoais. Conteúdos carregados de valores afetivos, porém, com um núcleo que parece inatingivel, abstrato, que molda e dá forma a esse conglomerado de ideias e emoções segundo os padrões típicos da espécie humana, o que Jung, chamou de arquétipos. (JUNG, 1907, p. 46). Segundo Jung, "os elementos da vida psíquica, sensações, representações e sentimentos, estão presentes na consciência, sob a forma de uma determinada unidade, que, por analogia com a química, pode-se comparar com as moléculas". Daí que, cada uma destas moléculas toma parte do tom afetivo da inteira massa de representações que nós definimos com o nome de "complexos de tonalidade afetiva". Tudo isto é explicado através do caráter estruturante atribuído a afetividade: "as representações particulares estão ligadas entre si, segundo as diversas leis das associações (semelhança, coexistência). Mas, o que as seleciona e as reagrupa em conjuntos maiores é um afeto" (JUNG, 1907, p. 48).

O termo afetividade exprime a esfera das emoções em sua interação com as dimensões motora e intelectual, enquanto que, a sexualidade encontra-se ligada com as noções de pares de opostos (masculino e feminino) e com a teoria do processo de individuação, onde representa simultaneamente o processo de diferenciação e o de integração da psique. A individuação se refere a um encontro consigo mesmo no sentido dado por Santo Agostinho "Não vás fora de ti, retorna a ti mesmo; no interior do homem é que reside a verdade" (JUNG, 1988, p. 107). O termo afetividade tornou-se genérico e passou a ser usado apenas como afeto que também é tantas vezes confundido com amor.

A palavra amor abre-se assim, para os mais variados níveis de compreensão; desde os estágios mais contemplativos como o "amor De $\imath$ " de ORÍGENES, o "amor intellectualis" de SPINOZA, o "amor da ideia" de PLATÃO,

Rev. Diálogo Educ., Curitiba, v. 9, n. 27, p. 363-378, maio/ago. 2009 
o "amor de Deus", dos místicos e prossegue com a conotação cristã de "amor ao próximo"; a budista de "compaixão", de filantropia, de serviço social; ao lado disso o "amor à pátria", etc. Depois vem o amor aos pais, sobretudo o "amor materno", e depois o "amor filial" (JUNG, 1993, p. 100). Todos esses níveis do amor se manifestam nos relacionamentos de forma geral, e com o relacionamento a dois chega-se àquela esfera que medeia entre espírito e instinto onde, por um lado, a pura chama do Eros incendeia o ardor da sexualidade e, por outro, se misturam formas ideais de amor como amor aos pais, amor à pátria e amor ao próximo com a ânsia de poder pessoal, o desejo de posse e de dominação. O contato com a esfera do instinto não representa necessariamente um rebaixamento, mas corre o risco de sufocar o amor, quando então mais irá se manifestar o lado animal (instintivo).

Aqui ainda não encontramos os limites do amor. Com a palavra "amor" "entendemos também o ato sexual em todos os níveis: desde a coabitação matrimonial, oficialmente sancionada, até a necessidade de descarga fisiológica" (JUNG, 1993, p. 101). A palavra amor pode cobrir ainda todo tipo de perversões da sexualidade assim como, todo tipo de abominação sexual doentia, que rebaixa o homem à condição de animal ou máquina. Também se encontram aí o amor incestuoso e um autoamor onanístico que pode ser chamado de narcisista no sentido de que se vive nos olhos do outro como se fosse um espelho idealizado, buscando reconhecimento, e quando não encontrado esse reconhecimento, mais frágil se torna enquanto indivíduo, isto porque, não reconhece a si mesmo. Cabe citar Jung quando o mesmo diz: "existem na nossa alma, mundos que são tão vastos quanto, infinitamente pequenos nós somos exteriormente, tão vastos que a evolução de uma nação ou de todo o universo poderia ocorrer no interior de nós mesmo" (JUNG, 1994, p. 59).

Caos moral e perda de valores geram amplas discussões sobre a extraordinária importância da sexualidade, que vão desde a culpa particular até as novas descobertas da ciência com todos os aparatos protetores e higiênicos de doenças venéreas e infecciosas até os transtornos psíquicos agudos relatados pelas psicopatologias. Enquanto o sexo implica (conceitualmente) a genitalidade mais especificamente, a sexualidade vai muito além. Está no toque, no abraço, na erotização do corpo do bebê, no olhar, na ausência. Está na voz, e também no silêncio. Está em todos os gestos do indivíduo mediante seu cotidiano. Está na beleza e no encanto do por do sol, do nascer da lua, do verde e das cores de todos os jardins e becos que os cercam. Está no canto dos pássaros, na garoa invernosa dos outonos. Está aí, dentro e fora de cada um. Cabe ao indivíduo, então, perceber que toda a paisagem é também uma extensão de si mesmo.

Todos os deuses da mitologia pulsam no fundo da alma e tecem suas tramas com fios de chumbo e ouro. Mas os grandes amantes são Eros, o deus do amor, e Psique sua consorte, ou a alma humana. Eros não se refere a um aspecto inferior da sexualidade, mas sim de um amor espiritual, um magnetismo que une

Rev. Diálogo Educ., Curitiba, v. 9, n. 27, p. 363-378, maio/ago. 2009 
o universo e convida o amor humano a participar desse campo magnetizado. Ele é divino, ela é humana. Eros é o princípio de ligação da relação. Uni-los dentro de si é a tarefa, pois toda dor e todo sofrimento nascem de sua separação e do ferimento causado. Separação necessária para que eles conheçam um ao outro e para que o ser humano possa conhecê-los. Eros e Psique estão em cada um individualmente e em todas as relações, mas nem sempre conscientes. Fala-se então das contrapartes do feminino e do masculino, anima e animus que são um modo de ser. Não se compreende essas dimensões psíquicas pela linguagem lógica e sim pela linguagem analógica.

A compreensão erótica começa com o conhecimento da própria alma: ou seja, com os seus desejos e as suas inclinações, os seus ciclos e as suas fases. Na poesia de Rilke é sugerido que para haver experiência criativa devemos viver em profundidade e este princípio é válido também para o sexo. Esta passagem chama a atenção para o fato de que, só se pode compreender a sexualidade, o sexo, o erotismo, com o conhecimento da própria alma.

Anima ou alma são sinônimos de Psique. Psique é uma dimensão interior constitutiva do ser humano cujo conhecimento é uma das tarefas principais da psicologia. $\mathrm{O}$ arquétipo da anima é a representação do feminino no homem e o animus é a representação do masculino na mulher. São personalidades interiores, imagens idealizadas, mas, como os indivíduos não os conhecem, os procuram fora, em outras pessoas, como se fossem as "almas gêmeas" ou coisa parecida. A anima é representada em imagens de uma jovem de rara beleza e a mais pura inocência. Assemelha-se a uma deusa e só se diferencia das deusas por ser humana. Assim ela nasce e reflete os dois lados de Eros, o lado escuro (desconhecido, inconsciente) e o lado luminoso (consciente). Todas as deusas poderão mostrar suas faces na Anima, sejam as deusas do sexo (Afrodite ou Vênus), do inferno (Perséfone ou Coré), do lar (Deméter ou Hera), da sabedoria (Diana ou Ártemis), entre outras tantas. Alguns aspectos da psique humana que são representados pelas deusas (arquétipos) aparecem no filme: A ODISSÉLA e tanto podem aprisionar quanto libertar os homens de seu fascínio. A anima representa, então, a ligação com a fonte da vida que está no inconsciente, para o homem é a representação da capacidade para amar e, quando interrompida esta ligação, o que se tem é uma estagnação, um endurecimento, levando o homem a um grande estado perturbador. A vida é aprisionada. O mesmo acontece com o animus na mulher, este quando positivo, representa a coragem, a iniciativa, a firmeza, a ação, o verbo e a espiritualidade no sentido amplo. Essas figuras além de inspirarem o arrebatamento amoroso podem permanecer prisioneiras dos complexos parentais quando estes são poderosos e negativos, pois inibem a pulsão de autonomia do indivíduo.

As representações de Eros são conhecidas de modo geral. Surge como um garotinho alado, atirando flechas, ou como um jovem adolescente alado com um alforje cheio de flechas e com uma delas voltada para alguma "vítima".

Rev. Diálogo Educ., Curitiba, v. 9, n. 27, p. 363-378, maio/ago. 2009 
Segundo Jung, em última instância, somos as vítimas e os instrumentos do amor. É o amor quem fere a anima e a faz sentir desejo, paixão, prazer, medo, ciúmes e todas as emoções que rondam a "ferida" causada pela flecha. Portanto a Anima é por assim dizer, o "lugar" do toque, da penetração da flecha, do olhar do outro. A flecha vem no olhar e como dizem os mitos pode ser uma flecha com ponta de chumbo ou uma flecha com ponta de ouro. Quando com ponta de chumbo é agressiva, dura, pode vir do pai, da mãe, do professor, do amigo; vem como castigo, punição, crítica negativa. Esse seria o polo negativo, obscuro de Eros. Quando com ponta de ouro é terna, cálida, amorosa, com paixão. Ambas estão no olhar, na palavra dita, na palavra não dita. Vem das mãos deste "outro" que é agora o oleiro que molda o vaso de barro.

Eros e flecha, na verdade, são um só e o modo como afetam o indivíduo é retratado nas relações. As flechas afetam. Provocam as mais variadas dimensões da afetividade, os afetos. Quem responde como afeto, quem é afetada, é a anima, a alma. Ela é o conjunto de emoções e imagens que acolhe ou se rebela. Eros e suas flechas são uma constante nas relações, une os corações apaixonados; aparece nos rostos que transmitem ira, apatia, indiferença, preocupação, ou, ainda, segurança, firmeza, confiança. Assim se é afetado, diretamente na dimensão mais íntima, a sexualidade. Porque se chama a dimensão mais íntima de sexualidade? Justamente por ser muito íntima. Por ser intimidade. A intimidade revela-se em duas direções aparentemente opostas que são denominadas de mundo interior e mundo exterior. Confunde-se intimidade e proximidade física com ato sexual. Intimidade é busca de cumplicidade, um acolher sem nada exigir, uma presença verdadeira e plena. Segundo o historiador Theodore Zeldin (1996, p. 291) em seu livro: Uma história intima da bumanidade:

A intimidade é uma parceria em busca da verdade, possibilitando à pessoa ver o mundo duas vezes, pelos olhos do parceiro e por seus próprios olhos. Penetrar na mente do outro não envolve submissão nem domínio: os parceiros tentam se auscultar, enquanto continuam a ser pessoas distintas [...] as diferenças de ambos lhes abrem a possibilidade de se ajudarem mutuamente a explorar, juntos ou em separado, o que não seria possível isoladamente.

Pode-se mover entre os mundos interno e externo e encontrar a ponte que os liga, ou seja: o símbolo. Quando se encontra o símbolo, vive-se uma vida simbólica rica de significados, o que acarretará uma vida sexual íntima e profunda, sadia e bela. A sexualidade revelar-se-á como um encanto pela vida cotidiana. Para isto precisa-se ser livre. Não no sentido de libertinos; apenas livres

Rev. Diálogo Educ., Curitiba, v. 9, n. 27, p. 363-378, maio/ago. 2009 
das prisões que cada um cria e nas quais se foi criado. Precisa-se transformar, dar novas formas, e às flechadas de chumbo de Eros, torná-las de ouro. Transformados, Eros será humanizado e Psique será divinizada.

Fala-se aqui de todo e qualquer tipo de relacionamento. Quando o amor, o respeito está presente, não existe lugar para os pré-conceitos. As relações heterossexuais não são privilegiadas. A homossexualidade sempre existiu e está presente nas sociedades ao longo da história e da cultura humana e não é surpreendente que ela seja expressa com uma ampla variedade de formas e seja vista de modos nitidamente contrastantes durante períodos históricos distintos e em diferentes sociedades. A homossexualidade é uma característica de quem sente atração física, emocional e espiritual por outras pessoas do mesmo sexo. O termo homossexual foi criado por um jornalista austro-húngaro chamado Karl-Maria Kertbeny em 1868. Está em desuso o termo homossexualismo, pois, na medicina, o sufixo ismo quer dizer doença. Usa-se o termo homossexualidade, pois, o sufixo dade significa modo de ser.

Em 1970, psiquiatras afirmavam que a homossexualidade era uma doença mental causada por processos fisiológicos, por desvios da orientação sexual e ainda por má formação e identificação sexual. Em 1993, o termo foi mundialmente retirado da lista de doenças mentais, já que não havia provas que confirmassem a veracidade do pronunciamento, e foi declarado que a homossexualidade era uma forma natural de desenvolvimento sexual. Sabe-se que o diferente, o desconhecido, sofre, à priori, grande rejeição. Não é diferente quando se fala de modos de ser da sexualidade. Esquece-se que o indivíduo que negue seus instintos, sua libido, que é a sua força viva, acaba por ficar desprovido também de toda possibilidade de realização. De que vale a busca de causas somente, se tudo se mostra no comportamento dos indivíduos. O Ocidente, impregnado de moralismo, quer queira quer não, há tantas gerações, ainda não está pronto para viver a proposta de que todo prazer físico e alegria do coração é em si, bom e justo. Privar-se dele por moralismo é tão falso quanto abusar dele por ignorância. Segundo Thomas Moore (1999, p. 199) em a Alma do sexo: "Moralismo é moralidade sem alma. É moralidade como um sintoma, um complexo neurótico que nos obceca e embota nosso julgamento. Não é moralidade verdadeira, mas uma tentativa fracassada de ser profundamente moral". Não se tem aqui a intenção de reduzir o sexo ao ato físico nem tampouco concentrar-se em uma ideia vaga e genérica da vida erótica, mas sim, mostrar que o Eros é um guia para um conhecimento de si mesmo e do outro.

Deve-se olhar para o sentido que sugere este diferente, para o caminho que perfaz esse modo de ser homossexual, bissexual, transexual; que atração é essa entre corpos que não buscam a reprodução humana e sim intimidade. Corpos que vivem a experiência de uma solidão, que se tornam muitas vezes

Rev. Diálogo Educ., Curitiba, v. 9, n. 27, p. 363-378, maio/ago. 2009 
escravos da moral, dos seus medos, no absurdo do qual eles e o mundo giram. Dividido entre aquilo que pressente de infinito nele e aquilo a que o mundo o reduz, terá forças de perseverar na busca de sentido em tudo isso?

Para Sheldrak (1994, p. 105):

Todas as formas e todos os padrões de coisas que se desenvolvem no mundo têm seus próprios campos de organização e todos derivam, em última análise, do campo unificado primordial, que continua a ser o campo do mundo, que abrange tudo.

Esta citação sugere aquele campo magnético de Eros que, sem levar em conta as formas e padrões do humano, faz o convite para a realização do amor. Quanta luta traçada em busca de direitos, mas esquece-se que o que se tem na homossexualidade (seja feminina ou masculina), na bissexualidade, na transsexualidade, são corpos. Corpos de homens e mulheres cheios de significados, que trazem em si uma psique (alma), assim como o potencial para ser aquilo que deles emergir. A busca, o anseio vivido por todos é pela eternidade. O que parece faltar nos relacionamentos é uma compreensão mais ampla de quem se é, como se está interagindo com o outro e com o mundo. O ser humano é presa da sensualidade porque sua vida conhece apenas as categorias dos sentidos, o agradável e o desagradável, e descuida do espírito. Que caminhos podem ser seguidos para este esclarecimento? Pode-se começar reconhecendo a linguagem utilizada quando se fala de sexo. De forma geral é uma linguagem muito física, idealizada ou ainda vulgar. O sexo é ainda uma atividade secularizada, egocêntrica e exploradora.

A noção de corpo está ainda fragmentada, dividida. Não se pode deixar de perceber que os estereótipos constituídos com base em metáforas de ordem biológica têm demonstrado uma grande capacidade de se manter, apesar das inconsistências que vão acumulando perante mudanças culturais, tecnológicas e políticas. Isso acontece até mesmo com aquelas vertentes que insistem no recurso de exagerar diferenças para encontrar, nos corpos, argumentos que garantam a continuidade de interpretações deterministas para comportamentos humanos e para a superioridade feminina ou masculina. A corporeidade como sendo a expressão máxima do que é ser humano precisa ser valorizada e revista como dimensão da totalidade, quando nesta dimensão, adentra-se na espiritualidade, que também é um modo de ser.

\section{A doença como símbolo}

A habilidade simbólica do ser humano o orienta no mundo. Os símbolos têm vida, atuam, alcançam dimensões que o conhecimento racional não

Rev. Diálogo Educ., Curitiba, v. 9, n. 27, p. 363-378, maio/ago. 2009 
pode atingir. Dizem respeito ao corpo do indivíduo, aos fenômenos do nascimento, da sexualidade e da morte. Sabe-se que é uma linguagem infinitamente rica, capaz de exprimir por meio de imagens muitas coisas que transcendem as problemáticas específicas dos indivíduos. Citando um comentário de Porfírio:

Empenha-te para te encontrares contigo mesmo, reunindo todos os membros dispersos, desunidos na multiplicidade, e originários da unidade que já existiu na grandiosidade de seu poder. Reúne e unifica as idéias inatas, tenta articular aquelas que ainda estão confusas e traze à luz aquelas que ainda se encontram na obscuridade. (JONAS, 1958, p. 61).

Isso sugere que o indivíduo ainda está fragmentado, parece que uma espessa camada de poeira ainda lhe cobre os olhos. Quando surge uma doença, vaise ao médico, e se espera radiografias, pílulas, intervenções cirúrgicas. Não é de praxe que se fale do modo como se está vivendo, dos sentimentos intensos que possam estar ligados à doença. Importante, porém, é voltar-se o olhar para a doença como expressão simbólica, onde não basta que se busquem as causas, mas a pesquisa de sua finalidade é imprescindível. No âmbito emocional, dir-se-ia que comportamentos como: envolvimento excessivo com o trabalho; sentimentos de urgência de tempo; hostilidade; agressividade; competitividade; impaciência; entre tantos outros, são fatores desencadeantes de doenças. O ser humano tem grande dificuldade em lidar com o imensurável, parece-lhe mais fácil atribuir ao externo e à matéria o poder que pertence à psique, prefere ainda pensar que qualquer efeito interno tem que ter uma causa externa. Esquece-se que o símbolo pode atuar sobre o corpo, provocando um sintoma ou ainda ajudando no processo de cura. O corpo faz uma imagem de si mesmo no cérebro. Chama-se a isso de imagem corporal ou ainda, imagem somática. A maneira como a expressão emocional do corpo aparece para o outro também é uma imagem somática.

Se o corpo cria uma imagem de si mesmo, vale aqui ver-se o mito como parte da matriz simbólica. O corpo tem uma capacidade inata para influenciar a si mesmo a partir da sua experiência emocional. Mito é corpo. Campbell afirma: "mitologia é uma canção, a canção da imaginação inspirada pelas energias do corpo" (KELEMAN, 1999 p. 11). A mente cria o mito, não a partir de seus programas racionais, mas em resposta a sugestões do corpo em relação àquilo de que ele necessita. Essa imagem criada pelo corpo deve ser reconhecida, criandose uma intimidade da própria estrutura corporal. Pergunta-se: que imagem temse de si mesmo?

É a imagem criada pelo social, a qual diz como se deve apresentar, ser ou estar no mundo ou é a imagem vivenciada por si mesmo? Quando satisfazendo a um coletivo somente, se está negando a própria imagem somática. Eis aqui um

Rev. Diálogo Educ., Curitiba, v. 9, n. 27, p. 363-378, maio/ago. 2009 
excelente motivo para adoecer. Coloca-se uma máscara, a qual se chama de persona, e vive-se em função de noções morais de como as pessoas acham que se deve interagir. Perde-se então, com isso, a autenticidade. Vê-se que no continuum os indivíduos tornam-se áridos, mal-humorados, passam a se relacionar com a vida de forma estreita e seca. Quando para os pedagogos o ensinar se torna algo obrigatório, um dever a ser cumprido somente, ele se distancia de algo prazeroso, da sensibilidade e da espontaneidade. Isola-se parte de si mesmo desta maneira. Para formar um indivíduo e uma entidade somática mais adulta, faz-se necessário o resgate de qualidades como: assertividade, ternura, compaixão no sentido de "sofrer com", lealdade a si mesmo entre outros. À medida que diminui a relação homem/natureza, que as abstrações aumentam na área de comunicação e educação, torna-se eficaz o resgate das origens somáticas, pois o corpo é a nossa continuidade.

$\mathrm{Na}$ atualidade, ainda separa-se o corpo, a mente e as emoções como se habitassem em compartimentos estanques e independentes uns dos outros, assim como está-se habituado a falar de sexo como uma realidade puramente física, e, de modo geral, assim fala-se também das coisas do mundo, como se nada mais tivesse alma. Enquanto vivido de forma doentia, o sexo deixa suas marcas no corpo. Os indivíduos, adultos, jovens ou crianças, carregam as marcas deixadas pelos abusos, pelas violências, pelas experiências marcadas de um sexo sem alma. Esse modo mecanicista de pensar traz implicações profundas para a sexualidade. Por pensar-se assim, os problemas sexuais são encarados de modo puramente mecânico. Sem mistério, sem profundidade, sem espiritualidade. Isto não quer dizer sem implicações. Todo envolvimento, de qualquer nível que seja, trará implicações profundas podendo precipitar o homem no pior caos emotivo. Para compreender a sexualidade é necessário ir além, e resgatar o encontro com a poesia, a arte, a natureza, enfim, a vida por ela mesma é prenhe de erotismo.

\section{O corpo como templo sagrado}

Quando se vive na dimensão da espiritualidade, não há espaço para os pré-conceitos, seja lá da espécie que for. O corpo é visto como templo sagrado, como expressão da criatividade e do conhecimento. Toda sabedoria e evolução física, psíquica, social e espiritual do mundo estão encarnadas nos corpos. A expressão se dá via inteligência, emoções, ideais e ideias.

O ser humano é uma síntese com uma finalidade espiritual. Não se pode pensar em alteridade num corpo reprimido, o amor só flui naturalmente onde essas amarras se dissolveram. A ética cristã surge de uma consciência integrada à afetividade, pois, o resgate da função afetiva é fundamental para um novo ponto de vista. O sentimento quando brota do indivíduo, dissolve os velhos

Rev. Diálogo Educ., Curitiba, v. 9, n. 27, p. 363-378, maio/ago. 2009 
paradigmas que o mantinham fixado a uma visão distorcida e unilateral da realidade. O Cristo dá o seu corpo e o seu sangue aos seus discípulos, e estes deverão comêlo e bebê-lo caso queiram passar pela transformação de consciência que os libertará da ignorância. Fala-se aqui de uma nova realidade, o corpo de Jesus é uma metáfora de sua mensagem, ele ultrapassa a intolerância pelo diferente, da consciência unilateral. Essa é a estrutura que necessita ser reconhecida.

Mas quando se fala em resgate da alma, a sair das categorias do sensual, cria-se uma barreira. Não só o homem prefere viver nelas, mas ama-as a tal ponto que se zanga quando lhe propõem viver com um sentido diferenciado. Como diz Jung (1988, p. 368):

É preferível para o indivíduo admitir a existência do afeto e submeter-se à sua violência, do que desembaraçar-se dele mediante operações mentais abstratas, sejam de qualquer espécie ou estados emocionais de fuga. Embora devido ao afeto o homem imite todas as más qualidades do ato de violência, tornando-se com isto culpado do mesmo erro, contudo, a finalidade deste acontecimento é precisamente penetrar no interior do homem fazendo com que ele se curve à sua ação. Por isso, é necessário que o homem seja afetado; contrariamente, essa ação não o atingirá. Mas é conveniente que o indivíduo saiba, ou melhor, tome conhecimento daquilo que o afetou, pois assim transformará em conhecimento a cegueira não só da violência, mas também do afeto.

Cada ser, do ponto de vista simbólico, traz em si as polaridades, espírito e alma, fogo e água; os princípios: ativo e passivo; consciente e inconsciente entre tantos outros. O sexo indica não só a dualidade do ser, mas sua bipolaridade e sua tensão, a realização plena do ser. Por isso os poemas místicos adotam a linguagem erótica para tentar expressar a inefável união da alma com o seu Deus. O amor é, portanto, condição essencial ao processo de autoconhecimento e realização de plenitude, chave para a espiritualização e para o resgate daquilo que se perdeu no processo de desenvolvimento biológico e social, razão das neuroses e do afastamento do Sagrado. Não há indivíduo amoroso distante do Numinoso, pois este leva o ser humano a sofrer a experiência da verdade que consequentemente leva a uma tremenda solidão, característica daqueles que se iniciam no caminho da transformação, sendo que caminho é um símbolo do movimento, das constantes transformações da vida. Quando se fala em corpo como templo sagrado, fala-se do re-conhecimento necessário do corpo enquanto uma inteligência própria, um nome próprio, um sopro, uma unidade na pluralidade; isso faz lembrar um comentário de Campbell que dizia

Rev. Diálogo Educ., Curitiba, v. 9, n. 27, p. 363-378, maio/ago. 2009 
mais ou menos assim: Quando se olha o planeta terra de cima para baixo, não se vê a divisão de estados, culturas, credos, raças, mas sim uma unidade. E assim é o corpo humano, quando olhado em sua totalidade, é micro inserido no macro cosmos, é a junção: alma, mente, espírito num só corpo.

\section{REFERÊNCIAS}

ABRAHAM, R.; MCKENNA, T.; SHELDRAKE, R. Caos, criatividade e o retorno do sagrado: triálogos nas fronteiras do ocidente. São Paulo: Cultrix; Pensamento, 1994.

JONAS, H. The gnostic religion. Boston: Beacon Press, 1958.

JUNG, C. G. Psicologia da religião ocidental e oriental. Petrópolis: Vozes, 1980. v. 11.

. O desenvolvimento da personalidade. Petrópolis: Vozes, 1986a. . Psicogênese das doenças mentais. Petrópolis: Vozes, 1986b. v. 3. . Civilização em mudança. Petrópolis: Vozes, 1993.

. Fundamentos de psicologia analítica. Petrópolis: Vozes, 1999.

KELEMAN, S. Mito e corpo. São Paulo: Summus, 1999.

MOORE, T. A alma do sexo. Rio de Janeiro: Ediouro, 1999.

ZELDIN, T. Uma história intima da humanidade. Rio de Janeiro: Record, 1996.

Recebido: 23/07/2008

Received: 07/23/2008

Aprovado: 05/08/2008

Approved: 08/05/2008

Revisado: 22/07/2009

Reviewed: 07/22/2009

Rev. Diálogo Educ., Curitiba, v. 9, n. 27, p. 363-378, maio/ago. 2009 